\title{
Antioxidant Activities of the Leaf Extract and Fractions of Dryopteris filix-mas (L.) Schott could be Attributed to The Abundance of Polyphenol Compounds
}

\author{
Earnest Oghenesuvwe Erhirhie ${ }^{1,2, *}$, Emmanuel Emeka Ilodigwe', Daniel Lotanna Ajaghaku ${ }^{3}$, \\ Blessing Ogechukwu Umeokoli ${ }^{4}$, Peter Maduabuchi Eze ${ }^{5}$, Festus Basden Chiedu Okoye ${ }^{4}$ \\ ${ }^{1}$ Department of Pharmacology and Toxicology, Faculty of Pharmaceutical Sciences, Nnamdi Azikiwe University, Awka, Nigeria. \\ ${ }^{2}$ Department of Pharmacology and Toxicology, Faculty of Pharmaceutical Sciences, Chukwuemeka Odumegwu Ojukwu University, Igbariam, Nigeria. \\ ${ }^{3}$ Department of Pharmacology, Faculty of Pharmaceutical Sciences, Enugu State University of Science and Technology, Enugu State, Nigeria. \\ ${ }^{4}$ Department of Pharmaceutical and Medicinal Chemistry Faculty of Pharmaceutical Sciences, Nnamdi Azikiwe University, Awka, Nigeria. \\ ${ }^{5}$ Department of Environmental Health Science, Faculty of Health Sciences and Technology, Nnamdi Azikiwe University, Nnewi campus, Anambra State, \\ Nigeria.
}

Corresponding author*

erhirhieochuko@yahoo.com, Tel: +234-7060434974

Manuscript received: 17 August, 2019. Revision accepted: 06 February, 2020. Published: 10 April, 2020.

\begin{abstract}
Dryopteris filix mas (D filix-mas) is wildly used in ethnomedicine for the management of rheumatoid arthritis, wounds and other diseases. We investigated the anti-oxidant activities of its leaf extract, and chromatographic fractions. The ethanol leaf extract was partitioned into four fractions; n-hexane, ethyl acetate, n-butanol and water. Ferric reducing anti-oxidant power (FRAP), 1, 1-diphenyl-2-picrylhydrazil $(\mathrm{DPPH})$ and nitric oxide (NO) scavenging in vitro assays were carried out on the extract and fractions at $6.25,12.5,25,50,100,200,400$ and $800 \mu \mathrm{g} / \mathrm{mL}$. The most active fraction (ethyl acetate fraction) was further purified using chromatographic techniques to isolate its major compound whose structure was elucidated using ID nuclear magnetic resonance (NMR) and mass spectrometry. The ethyl acetate fraction produced the highest free radical scavenging activity among the other fractions. The fraction (VLC-E7) from which the bioactive compound, quercetin-3-O- $\alpha$ L-rhamnopyranoside, was isolated had the best FRAP and DPPH scavenging activities with $\mathrm{EC}_{50}$ and IC 50 values of $88.81 \pm 3.41$ and $26.87 \pm 0.24$ respectively more than the ethyl acetate fraction. This study revealed that the polyphenol flavonoid, quercetin-3-O- $\alpha$ L-rhamnopyranoside could be responsible for antioxidant activity of ethno-medicinal property of $D$ filix-mas leaf.
\end{abstract}

Keywords: Dryopteris filix-mas; wounds; rheumatoid arthritis; quercetin-3-O- $\alpha$ L-rhamnopyranoside; anti-oxidant properties

\section{INTRODUCTION}

Free radicals are constantly produced in all normal living cells (Kumar et al., 2014). Imbalance between the production of these radicals and endogenous antioxidants creates a state of oxidative stress with its associated damaging effects on endogenous molecules such as lipids, proteins and nucleic acids (Yan et al., 2015). Unbridled oxidative stress has been reported to be implicated in several chronic and degenerative diseases such as diabetes, rheumatoid arthritis, cancer, neurodegenerative diseases, atherosclerosis, ischemic heart disease, ageing among others (Khatoon et al., 2013).

In attempt to ameliorating oxidative damages caused by free radicals, synthetic antioxidants such as butylated hydroxytoluene (BHT), butylated hydroxyanisole (BHA), and tert-butylhydroquinone (TBHQ) had been developed. However, these synthetic antioxidants left much to be desired due to their side effects, such as liver toxicity, carcinogenicity as well as their high cost and inaccessibility (Deepa et al., 2014). These limitations have inspired the search for more effective antioxidant from natural source, especially medicinal plants, which are biodegradable, less toxic, affordable and accessible (Ezeja et al., 2015; Ahlem et al., 2015).

$D$ filix-mas is an evergreen fern belonging to the family of Dryopteridaceae. Male fern, worm fern, aspidium and shield fern are common names assigned to it. It grows between $60-150 \mathrm{~cm}$ high and it is habitat to stream and moist environments (Uwumarongi et al., 2016). It is native to Europe, Asia, and North America. Its leaves are bipinnated and consist of 20-35 pinnae on each side of the rachis (Fig 1). Its stalks are covered with orange-brown scales (Bafor et al., 2017). The leaf decoction is ethno medicinally used in rheumatoid arthritis, wounds, bleeding disorders, ulcers, worm infestation and malaria (Tagarelli et al., 2010; Erhirhie et al., 2019). It is also reported as one of the ferns with 
useful secondary metabolites against chronic diseases and aging (Valentyna et al., 2017).

Previous studies have found that it possesses antihelmintic activity (Urban et al., 2014), antimicrobial activity (Mandal and Mondal, 2014), antidiarrheal (Uwumarongi et al., 2016), uterine relaxant (Bafor et al., 2017) and anti-inflammatory (Erhirhie et al., 2019) activities. A preliminary study by Sekender $e t$ $a l,(2012)$ revealed that it possesses anti-oxidant activity. In this present study, we evaluated the antioxidant activity of the leaf extract and fractions. The bioactive compound responsible for its antioxidant activity was isolated and characterized.

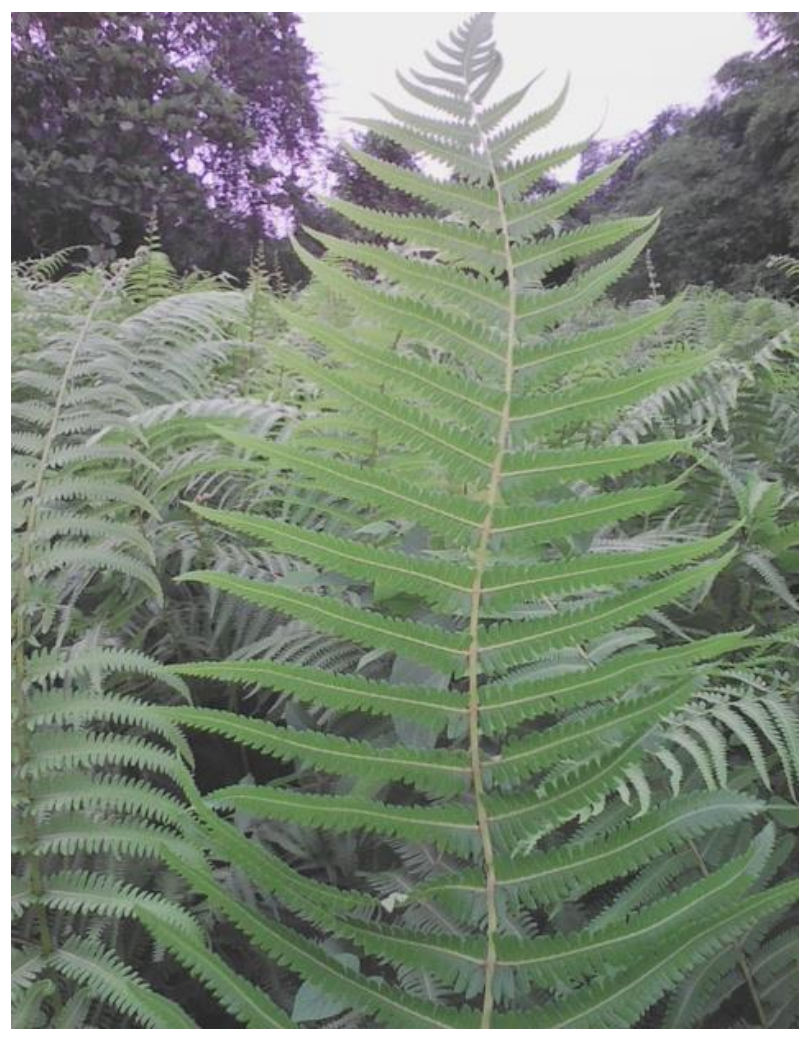

Figure 1. D. Filix-mas photograph.

\section{METHODOLOGY}

\section{Materials}

Visible Spectrophotometer (721g, Zhejiang, China), Thermostatic water bath (Equitron Mumbai India), Analytical weighing balance (Ohaus Corp. NJ USA), Quercetin (Institute of Pharmaceutical Biology and Biotechnology, Heinerich-Heine University, Dusselforf, Germany), 2,2-Diphennyl-1-picrylhydrazyl, DPPH (Sigma Aldrich), Ascorbic acid (Sigma- Aldrich).

\section{Procedure}

Plant collection, extraction, fractionation and purification of active compound

Plant collection, authentication, extraction, fractionation, chromatographic separation, and structural elucidation techniques were carried out using similar method as described in our earlier study (Erhirhie et al., 2019). The purification and structural elucidation was based on bioactivity guided antioxidant screening of liquid-liquid fractions (n-hexane, ethyl acetate, butanol, and water fractions), vacuum liquid chromatographic fractions and Sephadex fractions.

\section{DPPH scavenging assay}

The test was carried out based on the method described by Ajaghaku et al (2017). The reaction mixture contained $0.1 \mathrm{~mL}$ of various concentrations $(6.25,12.5$, $25,50,100,200,400$ and $800 \mu \mathrm{g} / \mathrm{mL}$ ) of sample, 0.1 $\mathrm{mL}$ of $0.6 \mathrm{mMol}$ of DPPH and $0.8 \mathrm{~mL}$ of methanol. The mixture was incubated in the dark for 30 minutes at room temperature. The absorbance of the sample was measured at $517 \mathrm{~nm}$ against blank (methanol) using a spectrophotometer. Ascorbic acid and quercetin were used as standards. A tube containing $0.1 \mathrm{~mL}$ of DPPH solution and $0.9 \mathrm{~mL}$ of methanol served as control. Experiments were carried out in duplicate. Free radical scavenging activities of each sample were determined as follows:

$D P P H$ scavenging activity $=(A C-A S) / A C) \times 100$ AC : Average absorbance of control

AS : Average absorbance of sample

A graph of percentage inhibition against concentration was plotted and the concentration that produced 50\% inhibition $\left(\mathrm{IC}_{50}\right)$ was extrapolated using a regression analyses equation.

\section{Ferric reducing antioxidant power (FRAP) assay}

FRAP assay was carried out following the method described by Habibur et al, (2013). Two hundred and fifty microliter $(0.25 \mathrm{~mL})$ of various concentrations, $6.25,12.5,25,50,100,200,400$ and $800 \mu \mathrm{g} / \mathrm{mL}$ of samples were mixed with $0.625 \mathrm{~mL}$ of phosphate buffer and $0.625 \mathrm{~mL}$ of $1 \%$ potassium ferricyanide $\left[\mathrm{K}_{3} \mathrm{FeCN}_{6}\right]$. The mixtures were heated at $50^{\circ} \mathrm{C}$ for 20 minutes. Then, $0.625 \mathrm{~mL}$ of $10 \%$ trichloroacetic acid (TCA) was added and the mixtures were centrifuged at $3000 \mathrm{rpm}$ for 10 minutes. From the upper layer, $0.625 \mathrm{~mL}$ was pipetted and mixed with $0.625 \mathrm{~mL}$ of distilled water and 0.125 $\mathrm{mL}$ of $0.1 \%(\mathrm{w} / \mathrm{v})$ ferric chloride $\left(\mathrm{FeCl}_{3}\right)$ solution. Absorbances of the mixtures were measured at $700 \mathrm{~nm}$ against air using a spectrophotometer. Ascorbic acid and quercetin were used as standards. Tests were performed in duplicate and percentage inhibition was calculated using the formula below.

$$
\begin{aligned}
& \% \\
& \frac{\text { Average absorbance of sample-Average absorbance of blank }}{\frac{100}{1}}
\end{aligned}
$$


A graph of percentage inhibition against concentration was plotted and the effective concentration $\left(\mathrm{EC}_{50}\right)$ was extrapolated using a regression analyses equation.

\section{Nitric oxide scavenging activity}

This assay was carried out following the method described by Ezeja et al., (2015). Two milliliter of 10 $\mathrm{mM}$ sodium nitroprusside prepared with phosphate buffer saline $(\mathrm{pH}$ 7.4) was mixed with $0.5 \mathrm{~mL}$ of samples at various concentrations $(6.25,12.5,25,50$, $100,200,400$ and $800 \mu \mathrm{g} / \mathrm{mL}$ ). The mixture was incubated at room temperature for 150 minutes. Thereafter, $0.5 \mathrm{~mL}$ of the reaction mixture was withdrawn and mixed with $0.5 \mathrm{~mL}$ of Griess reagent (1\% sulphanilamide $+0.1 \%$ naphthylethylenediamine dichloride $+3 \%$ phosphoric acid) was added to each test tube. The absorbance of the pink chromophore formed was measured at $540 \mathrm{~nm}$. Ascorbic acid and quercetin were used as standards. Assays were carried out in duplicates. Percentage inhibition was calculated using the formula below

$$
\frac{\text { Abs Control-Abs Test }}{\text { Abs Control }} \times \frac{100}{1}
$$

Inhibitory concentration, $\mathrm{IC}_{50}$ was estimated from graph of \% inhibition against concentration using regression analyses equation

\section{Statistical analysis}

Results were presented as mean \pm standard error of mean (SEM) using Statistical Package for Social Science (SPSS, version 20). Calculation of fifty percent inhibitory concentration $\left(\mathrm{IC}_{50}\right)$ of the extracts and fractions was carried out using regression equation in Microsoft Excel, 2010.

\section{RESULTS}

\section{DPPH, scavenging activity of extract and fractions}

In DPPH scavenging assay, 50\% inhibitory concentration $\left(\mathrm{IC}_{50}\right)$ of $134.12 \pm 2.88,94.97 \pm 0.14$, $63.91 \pm 1.29,62.09 \pm 0.21$ and $45.72 \pm 0.16 \mu \mathrm{g} / \mathrm{mL}$ were recorded in $n$-hexane, water fractions, extract, butanol and ethyl acetate fractions respectively. The ethyl acetate fraction produced the lowest $\mathrm{IC}_{50}$ value among other samples, except ascorbic acid and quercertin which showed $\mathrm{IC}_{50}$ values of $12.26 \pm 0.20 \mu \mathrm{g} / \mathrm{mL}$ and $10.46 \pm 0.15 \mu \mathrm{g} / \mathrm{mL}$ respectively (Table 1 ).

Inhibition against DPPH at $100 \mu \mathrm{g} / \mathrm{mL}$ by VLC fractions

Ethyl acetate VLC fractions, VLC-E1 (78.68\%), VLCE3 (52.33\%), VLC-E7 (72.38\%), VLC-E6 (73.84\%), VLC-E14 (65.60\%), VLC-E8 (73.08\%), VLC-E10 (74.81\%), VLC-E12 (72.09\%), VLC-E16 (69.67\%) produced more than $50 \%$ inhibition against DPPH (Table 2).
Table 1. Free radical (DPPH) scavenging activities of extract and fractions of $D$ filix-mas.

\begin{tabular}{ll}
\hline & $\begin{array}{l}\text { DPPH, scavenging activity, } \\
\text { IC50(ug/ml) }\end{array}$ \\
\hline Extract & $63.91 \pm 1.29$ \\
n-hexane fraction & $134.12 \pm 2.88$ \\
Ethyl-acetate fraction & $45.72 \pm 0.16$ \\
Butanol fraction & $62.09 \pm 0.21$ \\
Water fraction & $94.97 \pm 0.14$ \\
Ascorbic acid & $12.26 \pm 0.20$ \\
Quertcetin & $10.46 \pm 0.15$ \\
\hline
\end{tabular}

Values are expressed as mean \pm Standard error of mean.

Table 2. DPPH scavenging activities of ethyl acetate vacuum liquid chromatographic fractions of $D$ filix-mas.

\begin{tabular}{lll}
\hline Solvent ratio & Sample code & $\begin{array}{l}\text { Inhibition against } \\
\text { DPPH (\%) }\end{array}$ \\
\hline Ethyl acetate fraction & & 73.26 \\
N(500): E (0) & VLC-E1 & 78.68 \\
N(450): E (50) & VLC-E2 & 19.38 \\
N(400): E(100) & VLC-E9 & 18.12 \\
N(350): E(150) & VLC-E13 & 23.06 \\
N(300):E(200) & VLC-E4 & 28.00 \\
N(250): E(250) & VLC-E11 & 36.34 \\
N(200):E(300) & VLC-E3 & 52.33 \\
N(150):E(350) & VLC-E15 & 16.86 \\
N(100):E(400) & VLC-E5 & 12.79 \\
N(50): E(450) & VLC-E17 & 37.79 \\
N(0):E(500) & VLC-E7 & 72.38 \\
D(500):M(0) & VLC-E6 & 73.84 \\
D(450):M(50) & VLC-E14 & 65.60 \\
D(350):M(150) & VLC-E8 & 73.06 \\
D(250):M(250) & VLC-E10 & 74.81 \\
D(100):M(400) & VLC-E12 & 72.09 \\
D(0):M(500) & VLC-E16 & 69.67 \\
\hline
\end{tabular}

$\mathrm{N}=\mathrm{n}$-hexane, $\mathrm{E}=$ ethyl acetate, $\mathrm{M}=$ methanol.

Ferric reducing antioxidant power (FRAP), Nitric oxide (NO) and DPPH scavenging activities of extract selected fractions.

\section{FRAP activity}

In FRAP assay, quercetin and ascorbic acid produced the lowest $\mathrm{EC}_{50}$ values followed by VLC-E7, ethyl acetate fraction, extract and butanol fraction. In nitric oxide scavenging assay, ascorbic acid exhibited the lowest $\mathrm{IC}_{50}$ value $(14.74 \pm 0.11 \mu \mathrm{g} / \mathrm{ml})$ followed by ethyl acetate fractions $(15.38 \pm 3.65 \mu \mathrm{g} / \mathrm{ml})$ and butanol fractions $(15.45 \pm 2.72 \mu \mathrm{g} / \mathrm{ml})$, followed by VLC-E7 fraction $(16.66 \pm 0.48 \mu \mathrm{g} / \mathrm{ml})$, quercetin $(18.14 \pm 2.57$ $\mu \mathrm{g} / \mathrm{ml})$ and extract $(1854.60 \pm 200.25 \mu \mathrm{g} / \mathrm{ml})$. In DPPH assay, quercetin and ascorbic acid produced the lowest $\mathrm{IC}_{50}$ values $(11.50 \pm 0.08$ and $14.19 \pm 0.43 \mu \mathrm{g} / \mathrm{mL})$ followed by VLC-E7 $(26.87 \pm 0.24 \mu \mathrm{g} / \mathrm{mL})$, ethyl acetate fraction $(50.25 \pm 0.40 \mu \mathrm{g} / \mathrm{mL})$, butanol fraction $(62.09 \pm 0.21 \mu \mathrm{g} / \mathrm{mL})$ and crude extract $(63.91 \pm 1.29$ $\mu \mathrm{g} / \mathrm{mL}$ ) (Table 3). 


\section{DPPH, scavenging activity of Sephadex fractions}

DPPH scavenging activities of samples tested decreased in the following order; Quercetin $(10.46 \pm 0.15 \mu \mathrm{g} / \mathrm{mL})$ $>$ Ascorbic acid $(12.26 \pm 0.20 \mu \mathrm{g} / \mathrm{mL})>$ SPH-E3 $(26.35$ $\pm 1.38 \mu \mathrm{g} / \mathrm{mL})>$ VLC-E7 $(26.87 \pm 0.24 \mu \mathrm{g} / \mathrm{mL})>\mathrm{SPH}-$ E6 $(33.44 \pm 0.38 \mu \mathrm{g} / \mathrm{mL})>$ SPH-E5 $(37.30 \pm 0.30$ $\mu \mathrm{g} / \mathrm{mL})>$ SPH-E7 $(46.95 \pm 0.61 \mu \mathrm{g} / \mathrm{mL})>$ SPH-E4 $(86.10 \pm 7.69 \mu \mathrm{g} / \mathrm{mL})($ Table 4$)$.

Table 3. Ferric reducing antioxidant power (FRAP), Nitric oxide (NO) and DPPH scavenging activities of extract and fractions of $D$ filix-mas.

\begin{tabular}{llll}
\hline Sample & $\begin{array}{l}\text { FRAP, EC } \\
(\boldsymbol{\mu g} / \mathbf{m L})\end{array}$ & $\begin{array}{l}\text { Nitric oxide, } \\
\text { IC }_{\mathbf{5 0}}(\boldsymbol{\mu g} / \mathbf{m L})\end{array}$ & $\begin{array}{l}\text { DPPH, IC } \\
(\mathbf{u g} / \mathbf{m L})\end{array}$ \\
\hline Extract & $1854.60 \pm 200.25$ & $38.51 \pm 2.23$ & $63.91 \pm 1.29$ \\
\hline $\begin{array}{l}\text { Ethyl } \\
\text { acetate } \\
\text { fraction }\end{array}$ & $461.75 \pm 22.91$ & $15.38 \pm 3.65$ & $50.25 \pm 0.40$ \\
\hline $\begin{array}{l}\text { Butanol } \\
\text { fraction }\end{array}$ & $1911.03 \pm 137.44$ & $15.45 \pm 2.72$ & $62.09 \pm 0.21$ \\
\hline VLC-E7 & $88.81 \pm 3.41$ & $16.66 \pm 0.48$ & $26.87 \pm 0.24$ \\
\hline $\begin{array}{l}\text { Ascorbic } \\
\text { acid }\end{array}$ & $69.34 \pm 2.41$ & $14.74 \pm 0.11$ & $14.19 \pm 0.43$ \\
\hline Quercetin & $30.81 \pm 0.86$ & $18.14 \pm 2.57$ & $11.50 \pm 0.08$ \\
\hline
\end{tabular}

FRAP: Ferric reducing antioxidant power. Values are expressed as mean \pm Standard error of mean.

Table 4. DPPH scavenging activity, of Sephadex (SPH) fractions of D filix-mas.

\begin{tabular}{ll}
\hline & $\begin{array}{l}\text { DPPH, scavenging activity, } \\
\text { IC50 }(\boldsymbol{\mu g} / \mathbf{m L})\end{array}$ \\
\hline VLC-E7 & $26.87 \pm 0.24$ \\
SPH-E1 & - \\
SPH-E2 & $22.10 \pm 0.62$ \\
SPH-E3 & $26.35 \pm 1.38$ \\
SPH-E4 & $86.10 \pm 7.69$ \\
SPH-E5 & $37.30 \pm 0.30$ \\
SPH-E6 & $33.44 \pm 0.38$ \\
SPH-E7 & $46.95 \pm 0.61$ \\
Ascorbic acid & $12.26 \pm 0.20$ \\
Quercetin & $10.46 \pm 0.15$ \\
\hline
\end{tabular}

Values are expressed as mean \pm Standard error of mean.

\section{DISCUSSION}

It is well established that by-products of oxygen metabolism produce free radicals such as reactive oxygen and nitrogen species which results to cellular damage and pathogenesis of several diseases such as cancer, cardiovascular diseases, diabetes, neurodegenerative diseases among others ( $\mathrm{Li}$ et al., 2016).

There is a revitalization of interest in the search for natural anti-oxidant that could ameliorate reactive oxygen species which are implicated in numerous disease conditions (Ahlem et al., 2015; Deepa et al. 2014).
In this study, we investigated the antioxidant properties of the extract and fractions of $D$ filix-mas and also elucidated the major compound responsible for its antioxidant activity using in vitro bioassay guided isolation approach.

DPPH test is a widely acceptable and reproducible assay for screening potential antioxidants (Patel et al., 2010). This method involves the ability of anti-oxidants to donate electrons to DPPH thereby causing discoloration of the reaction mixture from deep violet color to yellow color (Patel et al., 2010). The yellow color change observed in this study substantiates the ability of the extract and fractions of $D$ filix-mas to scavenge free radicals generation by DPPH. This further suggests that the constituents present in the extract and fractions could ameliorate oxidative damages by free radicals.

Reduction of ferric $\left(\mathrm{Fe}^{3+}\right)$ to ferrous $\left(\mathrm{Fe}^{2+}\right)$ ions is a documented method of determining antioxidants with reducing power, capable of breaking free radical chain progression in lipid peroxidation (Habibur et al., 2013). From this study, reduction of iron (III) complex to the ferrous form, iron (II) could be a possible antioxidant mechanism as a result of the presence of reducing agents in the extract and fractions of $D$ filix-mas. Phenolic compounds such as quercetin has been reported to prevent free radicals by forming complex and chelating metal ions such as iron and cupper, thereby preventing auto-oxidative damage to the living system (Nimse and Pal, 2015).

Nitric oxide generated following incubation of sodium nitroprusside with phosphate buffer in the presence of oxygen is known to cause toxicity to biomolecules (Deepa et al., 2013). The scavenging capacities of the extract and fractions against nitric oxide generation suggest that $D$ filix-mas could prevent nitric oxide generation in various disease conditions. Polyphenols such as quercetin has been reported to interact with nitric oxide synthase resulting in modulation of nitric oxide production (Hussain et al., 2016).

The roles of phenolic compounds from medicinal plants as supplement in the treatment of oxidative stress and free radicals mediated tissue damage cannot the overemphasized (Li et al., 2016). Flavonoids and phenolic acids from polyphenols have been reported to play a significant role in scavenging free radicals and prevention of oxidative damage to cells. Phenolic compounds have capacity to neutralize several forms of oxidizing free radicals due to their electron donating abilities (Habibur et al., 2013; Ajaghaku et al., 2017). Ojo et al., (2013) reported that flavonoids inhibit lipid peroxidation in various biological systems. Presence of hydroxyl groups in flavonoids allows them to disconnect free radical chain reactions via the formation of intramolecular hydrogen bonds (Monika et al., 2011). 
From the forgoing, antioxidant properties elicited by the extract and fractions of $D$ filix-mas could be attributed to presence of flavonoids. This is substantiated by presence of the flavonoid, quercitrin - as the major compound in the HPLC chromatogram of the extract and fractions of $D$ filix-mas as documented in our earlier study (Erhirhie et al., 2019).

The ethyl acetate VLC fraction (VLC-E7), where the compound, quercetin-3-O- $\alpha$ L-rhamnopyranoside was isolated exhibited the highest anti-oxidant activity compared to the extract and other fractions. In line with this finding, quercetin-3-O- $\alpha$ L-rhamnopyranoside isolated from other medicinal plants was found to elicit significant antioxidant activity (Zhang et al., 2014). It is possible that possible that quercetin-3-O- $\alpha \mathrm{L}-$ rhamnopyranoside may be the key antioxidant compound of $D$ filix-mas.

Quercetin, the most widely distributed flavonoid in nature, existing mostly in its glycoside form quercitrin has been reported to possess various properties such as antioxidant, anti-inflammatory, neuroprotective, antiviral, anticancer, hepatoprotective, cardioprotective, antimicrobial and anti-obesity properties (Maalik et al., 2014). Mir, et al., (2017) reported that flavonoids from Tridax procumbens possess antioxidant properties. Phenolic compounds, catechin, epicathechin, dihydroquercetin isolated from Alchornea floribunda leaf were also found to elicit antioxidant properties (Ajaghaku et al., 2017).

In this study, the ability of extract and fractions of $D$ filix- mas to scavenge generation of free radicals from DPPH, nitric oxide as well as its chelating capacity could be attributed to the phenolic compound, quercetin3-O- $\alpha$ L-rhamnopyranoside, which was postulated to be responsible for its anti-inflammatory activity as earlier reported (Erhirhie et al., 2019).

\section{CONCLUSION}

The isolated flavonoid, quercetin-3-O- $\alpha \mathrm{L}-$ rhamnopyranoside from ethyl acetate chromatographed fraction of $D$ filix-mas could be responsible for its antioxidant activity, which validates its folkloric use in the management of rheumatoid arthritis and other free radical mediated diseases.

\section{Acknowledgments}

The authors are thankful to Prof. Dr. Peter Proksch of the Institute of Pharmaceutical Biology and Biotechnology, Heinrich-Heine University, Düsseldolf, Germany for making their facilities available for the High performance Liquid Chromatography (HPLC) and NMR analyses that were carried out. We are also thankful to Dr. H.A. Akinnibosun for assisting in the authentication of the plant specimen used for this study.

\section{REFERENCES}

Ahlem, R., Souad, I.B., Béatrice, B., Valérie, M.L., Fathi, M., Evelyne, O., Jamila, K.C and Malika, T.A., 2015, Total Phenolic, Total Flavonoid, Tannin Content, and Antioxidant Capacity of Halimium halimifolium (Cistaceae), JAPS, 5 (01): 052-057.

Ajaghaku, D.L., Obasi, O., Umeokoli, B.O., Ogbuatu, P., Nworu, C.S., Ilodigwe, E.E., and Okoye, F.B.C., 2017, In vitro and in vivo antioxidant potentials of Alchornea floribunda leaf extract, fractions and isolated bioactive compounds, Avicenna J Phytomed, 7 (1): 80-92.

Bafor, E.E., Omokaro, W.O., Uwumarongie, O.H., Elvis-Offiah, U.B., Omoruyi, O, Viegelmann, C.V. and Edrada-Ebel, R., 2017. Dryopteris filix-mas (Dryopteridaceae) leaves inhibit mouse uterine activity. Journal of Medicinal Plants for Economic Development, 1(1):1-12.

Deepa, M. and Renuka, D., 2014, Potent anti-inflammatory medical plant-a review, Int J Pharm Pharm Sci., 6 (4):43-49.

Erhirhie EO, Emeghebo CN, Ilodigwe EE, Ajaghaku DL, Umeokoli BO, Eze PM, Ngwoke KG, Okoye FBC. Dryopteris filix-mas (L.) Schott ethanolic leaf extract and fractions exhibited profound anti-inflammatory activity. Avicenna J Phytomed, 2019; 9(4): 396-409.

Ezeja, M.I., Yusuf, N., Omeh, S., Onoja, O. and Ijeoma, H.U., 2015, Antiinflammatory and Antioxidant Activities of the Methanolic Leaf Extract of Cissus aralioides, Am J Pharmacol Sci, 3 (1): 1-6.

Habibur, R., Manjula, K., Anoosha, T., Nagaveni, K., Chinna, M.E., and Dipankar, B., 2013, In-vitro antioxidant activity of Citrulus lanatus seed extracts, Asian Journal of Pharm. Clin. Res. 6 (3): 152-157.

Hussain T.,Tan, B., Yin, Y., Blachier, F., Tossou, M.C.B., Rahu N., 2016. Oxidative Stress and Inflammation: What Polyphenols Can Do for Us. Hindawi Publishing Corporation

Oxidative Medicine and Cellular Longevity Volume 2016, Article ID 7432797, 9 pages http://dx.doi.org/10.1155/2016/7432797

Khatoon, M., Islam, E, Islam, R., Rahman, A.A., Alam, A.H.M.K., Khondkar, P., Rashid, M. and Parvin, S., 2013, Estimation of total phenol and in vitro antioxidant activity of Albizia procera leaves, BMC Res Notes. 6:121. 1-7.

Kumar, S., Sandhir, R. and Ojh, S., 2014, Evaluation of antioxidant activity and total phenol in different varieties of Lantana camara leaves, BMC Res Notes. 7:560.1-7.

Li J., Liu X., Shen L., Zeng W., Qiu G., 2016, Natural plant polyphenols for alleviating oxidative damage in man: Current status and future perspectives Tropical Journal of Pharmaceutical Research; 15 (5): 1089-1098.

Maalik, A., Farhan, A.K., Amara, M., Adeem, M., Saira, A., Muhammad, A., Sabiha, K., Yasir, A. and Imran, T., 2014, Pharmacological Applications of Quercetin and its Derivatives: A Short Review, Trop J Pharm Res, 13 (9): 1561-1566.

Mandal, A. and Mondal, A.K., 2014, Studies on antimicrobial activities of some selected ferns and lycophytes in Eastern India with special emphasis on ethno-medicinal uses, Afr. $J$. Plant Sci, 5(7):412-420.

Mir, S.A, Jan, Z., Mir, S., Dar, A.M. and Chitale, G., 2017, A Concise Review on Biological Activity of Tridax procumbens Linn, Organic Chem Curr Res, 6: 177.

Monika, M., Michae S., Maegorzta P. and Hanna, C., 2011, Evaluation of antioxidant potential of flavonoids: An in vitro study, Acta Pol Pharm, 68 (4):611-615. 
Nimse, S.B., Pal, D., 2015. Free radicals, natural antioxidants, and their reaction mechanisms. Royal Society of Chemistry, 5, 27986-28006. doi: 10.1039/C4RA13315C.

Ojo, O.A., Oloyede, O.I., Olarewaju, O.I., Ojo, A.B., Ajiboye, B.O. and Onikanni, S.A., 2013, Toxicity Studies of the Crude Aqueous Leaves Extracts of Ocimum gratissimum in Albino Rats, IOSR-JESTFT, 6 (4):34-39.

Patel, A., Patel, A., Patel, N.M., 2010, Determination of polyphenols and free radical scavenging activity of Tephrosia purpurea Linn.leaves (Leguminosae), Pharmacogn Res. 2:152-8.

Sekendar, A.M., Mostafa, K., Raihan, M.O., Rahman, M.K., Hossain, M.A. and Alam, M.S., 2012, Antioxidant and Cytotoxic activities of Methanolic extract of Dryopteris filixmas (L.) Schott Leaves, Int. j. drug dev. res, 4(2): 223-229.

Tagarelli, G., Tagarelli, A. and Piro, A., 2010, Folk medicine used to heal malaria in Calabria (southern Italy), J Ethnobiol Ethnomed, 6 (27): 1-16.

Urban, J., Tauchen, J., Langrova, I. and Kokoska, L., 2014, In vitro motility inhibition effect of Czech medicinal plant extracts on Chabertia ovina adults, J. Anim. Plant Sci, 21(2): 3293-3302.

Uwumarongie, H.O., Enike, M.A. and Bafor, E.E., 2016, Pharmacognostic evaluation and gastrointestinal activity of Dryopteris filix-mas (L.) schott (Dryopteridaceae), Ew J Herbal ChemPharmacol Res, 2(1): 19-25.

Valentyna, M., Iryna, T., Tetyana, D. and Larysa, M., 2017, A review of the medicinal ferns of Ukraine, Scr. Sci. Pharm, 4 (1): 46-62.

Yan, H., Yuan, Y., Xi, Z., Kun, Z., Shaohua, C. and Zhiyun, D., 2015. Curcumin, Inflammation, and Chronic Diseases: How Are They Linked? Molecules, 20, 9183-9213; doi:10.3390/molecules20059183.

Zhang, Y., Wang, D., Yang, L., Zhou, D., Zhang, J. 2014, Purification and Characterization of Flavonoids from the Leaves of Zanthoxylum bungeanum and Correlation between Their Structure and Antioxidant Activity, PLoS ONE, 9(8): e105725. doi: 10.1371/journal.pone.010572. 